\title{
Author Correction: All-optical switching of an epsilon-near-zero plasmon resonance in indium tin oxide
}

\author{
Justus Bohn (1), Ting Shan Luk, Craig Tollerton, Sam W. Hutchings, Igal Brener (D), Simon Horsley (D), \\ William L. Barnes (1) \& Euan Hendry
}

Correction to: Nature Communications https://doi.org/10.1038/s41467-021-21332-y, published online 15 February 2021.

The original version of the Supplementary Information associated with this Article contained an error in Supplementary Figure 5, in which panel $c$ of Supplementary Figure 5 had an error on the vertical axis. The HTML has been updated to include a corrected version of the Supplementary Information.

Published online: 04 March 2021

\section{Additional information}

Supplementary information The online version contains supplementary material available at https://doi.org/10.1038/s41467-021-22020-7.

Open Access This article is licensed under a Creative Commons Attribution 4.0 International License, which permits use, sharing, adaptation, distribution and reproduction in any medium or format, as long as you give appropriate credit to the original author(s) and the source, provide a link to the Creative Commons license, and indicate if changes were made. The images or other third party material in this article are included in the article's Creative Commons license, unless indicated otherwise in a credit line to the material. If material is not included in the article's Creative Commons license and your intended use is not permitted by statutory regulation or exceeds the permitted use, you will need to obtain permission directly from the copyright holder. To view a copy of this license, visit http://creativecommons.org/licenses/by/4.0/.
}

(C) The Author(s) 2021 